\title{
2017 年香港の日本語学習者背景調査 \\ The 2017 survey of Japanese language learners in Hong Kong
}

\section{山下 直子、梁 安玉、劉 礪志、李 澤森、李 夢娟 \\ 香港日本語教育研究会}

\section{1.はじめに}

日本政府観光局（2017）によると、香港の訪日旅行者数は2016年、1,839,193人 （前年比伸び率 $20.7 \%$ ）で過去最高を更新した。

香港日本語教育研究会（以下、研究会）が香港の日本語学習者を対象とした調査 （木山ほか 2011、宇田川ほか 2014、山下ほか 2016 など）における香港の日本語 学習者の学習目的は「日本に旅行に行くため」という割合が上位であることは調査 以来変化がない。

では、実際に日本語学習者にとって「日本旅行」と「日本語学習」はどのように 関連しているのか。また、韓国語学習の人気等から日本語学習者の減少（国際交流 基金2013、瀬尾ほか2012、宇田川ほか2013,2014）や日本語学習の継続について課題 が挙げられている。そこで、日本旅行と日本語学習の関係、日本語学習の継続要因、 日本語学習の価值や意義についての学習者意識を明らかにしたい。

\section{2. 先行研究}

\section{1 日本語学習と日本旅行}

瀬尾（2011）は、日本語生涯学習者に対する調査において、日本語学習を始めた きかっけとして日本旅行を概念化している。日本旅行の際、デパートでの買い物で 店員は英語が全然わからず、日本語を勉強したいと思ったというインタビュー結果 を報告している。また、山下ほか（2017）では、質問紙調査において「日本旅行を するとき日本語がわかると役に立つ」ことが学習動機の大きな要因であり、年少者、 成人と年齢を問わず最も多い回答であったことを明らかにしている。日本語学習と 日本旅行が目的や動機づけにおいて深い関係性があることはわかった。しかし、 これまで香港の日本語学習者を対象にした調査において、日本旅行における具体的 な日本語使用場面や機会に関する調查は管見の限りない。どのような場面で関係が 深いのか。

\section{2 日本語学習者の減少対策と継続要因}

香港において日本語学習者の減少の一因として韓国語学習の人気が考えられて いた（瀬尾ほか2012、宇田川ほか 2014）。しかし、瀬尾（2016）によると、韓国語 学習人気が日本語学習の継続に直接影響しているものではないと分析している。 
瀬尾ほか（2012）では、生涯学習機関において学習者減少の打開策を模索し なければならないと述べている。また、小玉（2017）も韓国語ではなく、学習者 減少の対処方法を現行の日本語教育のなかから構築する必要性を述べている。

瀬尾（2011）は、日本語学習を続ける理由として「日本文化」、「日本語が理解 できる喜び」、「つながり」、「日本語を忘れないため」を概念化している。具体的に どのようなものが日本語学習者の減少対策となり継続につながるのか。

\section{3 日本語学習の価値と意義}

板井（2001）ほか、これまで「趣味」としての日本語学習という報告がされ続け ている香港において、その学習意義はどこにあるのか。山下ほか（2017）では、 興味関心対象である日本旅行について「日本旅行をするときに日本語がわかると 役に立つ」という学習動機の要因は実用的価值認識であると分析している。さらに

「日本語を勉強すると世界が広がる」という期待的価值も明らかにした。しかし、 これらの調査は先行研究をもとに作成した選択式の質問紙調査であった。学習者 自らことばを選び日本語学習の意義について表現してもらう必要があるのでは ないか。

\section{3. 目的}

本調査は、以下3点を明らかにすることを目的とする。

（1）日本旅行における日本語の使用機会はどの場面か

（2）日本語学習の継続に必要なものは何か

（３）日本語学習の意義とは何か

\section{4. 調查方法}

1 ）対象者：2017 年 6 月に研究会が実施した JLPT 応募者（N3、N4、N5 の 応募者のみ）を対象とした調査活動のために集まった香港の日本語 学習者

2 ）調査方法：調查協力者は質問紙に記入する方法で回答し、研究会の担当者が 回収する。質問紙は選択回答と自由記述回答式で、調査協力者が N3、N4、N5 レベルのため、質問紙は中国語（繁体字）で作成 したものを使用した。

3 ）集計方法：表計算機能のあるコンピュータープログラムにデータ入力し、 集計した。中国語で書かれたものは日本語訳をした。 


\section{5. 集計結果}

\section{1 調查協力者}

調査協力者は 592 人で、N3は 232 人、N4は237人、N5は 123 人である。レベルと 年齢の内訳は以下の表1の通りである。

表 1 レベル別年齢内訳

\begin{tabular}{|c|c|c|c|cc|}
\hline & $\mathrm{N} 3$ & $\mathrm{~N} 4$ & $\mathrm{~N} 5$ & \multicolumn{2}{|c|}{ 合計 (割合) } \\
\hline $8-11$ 歳 & 1 & 0 & 3 & 4 & $(0.68 \%)$ \\
\hline $12-17$ 歳 & 25 & 16 & 17 & 58 & $(9.80 \%)$ \\
\hline $18-22$ 歳 & 79 & 58 & 24 & 161 & $(27.20 \%)$ \\
\hline $23-29$ 歳 & 78 & 87 & 37 & 202 & $(34.12 \%)$ \\
\hline $30-39$ 歳 & 35 & 48 & 22 & 105 & $(17.74 \%)$ \\
\hline $40-49$ 歳 & 12 & 17 & 17 & 46 & $(7.77 \%)$ \\
\hline $50-59$ 歳 & 2 & 10 & 2 & 14 & $(2.36 \%)$ \\
\hline $60-69$ 歳 & 0 & 1 & 1 & 2 & $(0.34 \%)$ \\
\hline & 232 & 237 & 123 & 592 & \\
\hline
\end{tabular}

学習の場について、「学校」の科目として日本語を学習しつつ、語学学校など ほかの場でも学習している調查協力者（以下、協力者）もいると想定されたため、 複数回答可とした。民間の語学学校や塾が一番多いが、独学の割合も高い。

表 2 学習の場

\begin{tabular}{|l|c|c|c|cc|}
\hline & $\mathrm{N} 3$ & $\mathrm{~N} 4$ & $\mathrm{~N} 5$ & \multicolumn{2}{|c|}{ 合計（割合） } \\
\hline 1. 学校 & 32 & 26 & 12 & 70 & $(10.61 \%)$ \\
\hline 2. 庖間の語学学校·塾 & 83 & 123 & 76 & 282 & $(42.73 \%)$ \\
\hline 3. 個人授業 & 11 & 20 & 12 & 43 & $(6.52 \%)$ \\
\hline 4. 通信教育 & 3 & 2 & 1 & 6 & $(0.91 \%)$ \\
\hline 5. 独学 & 132 & 85 & 42 & 259 & $(39.24 \%)$ \\
\hline
\end{tabular}

\section{2 調查結果}

\subsection{1 日本旅行中の日本語の使用機会場面}

「（日本にいったとき）、日本語を使うチャンスがありますか」という８項目の質問 で、「とてもある」、「少しある」、「あまりない」、「全くない」の 4 つの選択肢から 選んで答える。「1. 買い物するとき」、「2. 食事をするとき」、「5. 街中で（道を探す ときなど)」の場面で日本語を使う機会が多い。N3 の協力者はその 3 場面だけで 
なく、す心゙ての場面において「とてもある」と答えている協力者が N4、N5 のより 多い。一方、「6. コンサートなどイベントに参加するとき」、「7. 日本の友達と会う とき」、「8. 体験教室（和菓子作り、浴衣など）に参加するとき」の場面では日本語 を使う機会は「全くない」という回答が多かった。

表 3 日本語の使用機会場面

\begin{tabular}{|c|c|c|c|c|c|}
\hline 項目 & レベル & とてもある & 少しある & あまりない & 全くない \\
\hline \multirow{3}{*}{ 1. 買い物するとき } & N3 & 92 & 80 & 23 & 5 \\
\hline & $\mathrm{N} 4$ & 77 & 101 & 31 & 8 \\
\hline & N5 & 22 & 50 & 22 & 7 \\
\hline \multirow{3}{*}{ 2. 食事するとき } & N3 & 89 & 84 & 23 & 3 \\
\hline & $\mathrm{N} 4$ & 77 & 101 & 31 & 8 \\
\hline & N5 & 29 & 47 & 16 & 9 \\
\hline \multirow{3}{*}{$\begin{array}{l}\text { 3. 移動する(交通手段を } \\
\text { 使う)とき }\end{array}$} & N3 & 48 & 55 & 74 & 23 \\
\hline & $\mathrm{N} 4$ & 27 & 59 & 88 & 43 \\
\hline & N5 & 8 & 27 & 44 & 22 \\
\hline \multirow{3}{*}{ 4. 宿泊するとき } & N3 & 48 & 74 & 56 & 22 \\
\hline & $\mathrm{N} 4$ & 29 & 80 & 75 & 33 \\
\hline & N5 & 11 & 34 & 41 & 15 \\
\hline \multirow{3}{*}{$\begin{array}{l}\text { 5. 街中で(道を探すとき } \\
\text { など) }\end{array}$} & N3 & 78 & 62 & 47 & 13 \\
\hline & $\mathrm{N} 4$ & 47 & 78 & 63 & 29 \\
\hline & N5 & 21 & 33 & 24 & 22 \\
\hline \multirow{3}{*}{$\begin{array}{l}\text { 6. コンサートなどイベント } \\
\text { に参加するとき }\end{array}$} & N3 & 28 & 20 & 41 & 109 \\
\hline & $\mathrm{N} 4$ & 13 & 29 & 43 & 132 \\
\hline & N5 & 7 & 7 & 19 & 66 \\
\hline \multirow{3}{*}{ 7. 日本の友達と会うとき } & N3 & 59 & 47 & 18 & 74 \\
\hline & $\mathrm{N} 4$ & 40 & 52 & 23 & 102 \\
\hline & N5 & 8 & 19 & 15 & 57 \\
\hline \multirow{3}{*}{$\begin{array}{l}\text { 8. 体験教室 (和菓子 } \\
\text { 作り、浴衣など)に } \\
\text { 参加するとき }\end{array}$} & N3 & 47 & 51 & 36 & 64 \\
\hline & $\mathrm{N} 4$ & 21 & 60 & 56 & 80 \\
\hline & N5 & 6 & 24 & 22 & 48 \\
\hline \multirow{3}{*}{ 9. その他 } & \multicolumn{5}{|c|}{ ·交流プログラム、交通事故後の警察とのやりとり } \\
\hline & \multicolumn{5}{|c|}{ · 入国、短期留学、仕事 } \\
\hline & \multicolumn{5}{|c|}{ ·博物館に見学に行く } \\
\hline
\end{tabular}




\subsection{2 日本語学習の継続に必要なもの}

「あなたが今後も日本語を続けるために、何が必要ですか」という 18 項目の質問 に「とても重要」、「少し重要」、「あまり重要でない」、「全く重要でない」の 4 つの 選択肢から選んで答える。「とても重要」に多く回答があった項目はレベルを問わず 「3.旅行に役立つこと」、「4.自分の趣味（アニメ、ゲームなど）に役立つこと」、 「17.自分にやる気があること」、「18.日本や日本語自体に魅力があること」の 4 項目であった。N3 の協力者は「とても重要」に「1.就職、進学などに役立つこと」、

「7. 日本語や日本文化に触れる機会があること」、「8.日本人と交流する機会がある こと」に回答が多かった。一方、「あまり重要でない項目としては、レベルを問わず 「6.奨学金やCEF など金銭的援助があること」、「9.スピーチコンテストなど実力を 披露できる機会があること」の 2 項目であった。また、「11. 一緒に勉強する友達や 仲間がいること」ではN 2 と N5 の協力者、「15.先生、上司、友達などに評価される こと」にはN5 の協力者の回答が少なかった。

表 4 日本語継続に必要なもの

\begin{tabular}{|c|c|c|c|c|c|}
\hline 項目 & レベル & $\begin{array}{l}\text { とても } \\
\text { 重要 }\end{array}$ & $\begin{array}{l}\text { 少し } \\
\text { 重要 }\end{array}$ & $\begin{array}{c}\text { あまり } \\
\text { 重要でない }\end{array}$ & $\begin{array}{c}\text { 全く重要 } \\
\text { でない }\end{array}$ \\
\hline \multirow[t]{3}{*}{ 1. 就職、進学などに役立つこと } & N3 & 103 & 90 & 33 & 6 \\
\hline & N4 & 81 & 92 & 48 & 16 \\
\hline & N5 & 34 & 45 & 40 & 3 \\
\hline \multirow{3}{*}{$\begin{array}{l}\text { 2. 試験に合格でき、資格が } \\
\text { 取れること }\end{array}$} & N3 & 90 & 104 & 33 & 5 \\
\hline & $\mathrm{N} 4$ & 79 & 106 & 41 & 11 \\
\hline & N5 & 38 & 53 & 27 & 4 \\
\hline \multirow[t]{3}{*}{ 3. 旅行に役立つこと } & N3 & 130 & 96 & 4 & 2 \\
\hline & $\mathrm{N} 4$ & 124 & 102 & 9 & 2 \\
\hline & N5 & 69 & 50 & 1 & 2 \\
\hline \multirow{3}{*}{$\begin{array}{l}\text { 4. 自分の趣味（アニメ、ゲーム } \\
\text { など）に役立つこと }\end{array}$} & N3 & 148 & 72 & 10 & 2 \\
\hline & N4 & 124 & 98 & 12 & 3 \\
\hline & N5 & 66 & 45 & 8 & 3 \\
\hline \multirow{3}{*}{$\begin{array}{l}\text { 5. 将来、役に立たなくても } \\
\text { 楽しめること }\end{array}$} & N3 & 85 & 90 & 49 & 8 \\
\hline & N4 & 72 & 122 & 37 & 6 \\
\hline & N5 & 31 & 73 & 11 & 7 \\
\hline
\end{tabular}




\begin{tabular}{|c|c|c|c|c|c|}
\hline 項目 & レベル & $\begin{array}{c}\text { とても } \\
\text { 重要 }\end{array}$ & $\begin{array}{l}\text { 少し } \\
\text { 重要 }\end{array}$ & $\begin{array}{c}\text { あまり } \\
\text { 重要でない }\end{array}$ & $\begin{array}{l}\text { 全く重要 } \\
\text { でない }\end{array}$ \\
\hline \multirow{3}{*}{$\begin{array}{l}\text { 6. 奨学金や CEF など金銭的 } \\
\text { 援助があること }\end{array}$} & N3 & 26 & 50 & 106 & 50 \\
\hline & $\mathrm{N} 4$ & 23 & 68 & 89 & 57 \\
\hline & N5 & 28 & 34 & 40 & 20 \\
\hline \multirow{3}{*}{$\begin{array}{l}\text { 7. 日本語や日本文化に触れる } \\
\text { 機会があること }\end{array}$} & N3 & 120 & 99 & 11 & 2 \\
\hline & $\mathrm{N} 4$ & 96 & 130 & 10 & 1 \\
\hline & N5 & 50 & 64 & 6 & 2 \\
\hline \multirow{3}{*}{$\begin{array}{l}\text { 8. 日本人と交流する機会が } \\
\text { あること }\end{array}$} & N3 & 121 & 97 & 12 & 2 \\
\hline & $\mathrm{N} 4$ & 105 & 109 & 20 & 3 \\
\hline & N5 & 51 & 60 & 11 & 0 \\
\hline \multirow{3}{*}{$\begin{array}{l}\text { 9. スピーチコンテストなど } \\
\text { 実力を披露できる機会が } \\
\text { あること }\end{array}$} & N3 & 11 & 28 & 122 & 71 \\
\hline & $\mathrm{N} 4$ & 7 & 29 & 121 & 80 \\
\hline & N5 & 6 & 17 & 64 & 35 \\
\hline \multirow{3}{*}{$\begin{array}{l}\text { 10. 日本語の上達が実感できる } \\
\text { こと }\end{array}$} & N3 & 99 & 115 & 15 & 3 \\
\hline & $\mathrm{N} 4$ & 90 & 130 & 14 & 3 \\
\hline & N5 & 47 & 63 & 9 & 3 \\
\hline \multirow{3}{*}{$\begin{array}{l}\text { 11. 一緒に勉強する友達や } \\
\text { 仲間がいること }\end{array}$} & N3 & 28 & 67 & 94 & 43 \\
\hline & $\mathrm{N} 4$ & 22 & 87 & 85 & 43 \\
\hline & N5 & 15 & 43 & 45 & 19 \\
\hline \multirow{3}{*}{$\begin{array}{l}\text { 12. ひとりで勉強できる教材や } \\
\text { 環境（インターネットなど） } \\
\text { が充実していること }\end{array}$} & N3 & 63 & 111 & 48 & 10 \\
\hline & $\mathrm{N} 4$ & 53 & 136 & 42 & 6 \\
\hline & N5 & 31 & 53 & 32 & 6 \\
\hline \multirow[t]{3}{*}{ 13. よい学校や機関があること } & N3 & 51 & 104 & 61 & 16 \\
\hline & $\mathrm{N} 4$ & 53 & 145 & 32 & 7 \\
\hline & N5 & 29 & 63 & 24 & 6 \\
\hline \multirow{3}{*}{$\begin{array}{l}\text { 14. 家族、先生、友達などの } \\
\text { サポートがあること }\end{array}$} & N3 & 43 & 102 & 64 & 23 \\
\hline & $\mathrm{N} 4$ & 27 & 126 & 67 & 17 \\
\hline & N5 & 22 & 51 & 34 & 15 \\
\hline \multirow{3}{*}{$\begin{array}{l}\text { 15. 先生、上司、友達などに } \\
\text { 評価されること }\end{array}$} & N3 & 40 & 94 & 73 & 25 \\
\hline & $\mathrm{N} 4$ & 24 & 103 & 79 & 30 \\
\hline & N5 & 23 & 39 & 45 & 15 \\
\hline
\end{tabular}




\begin{tabular}{|c|c|c|c|c|c|}
\hline 項目 & レベル & $\begin{array}{l}\text { とても } \\
\text { 重要 }\end{array}$ & $\begin{array}{l}\text { 少し } \\
\text { 重要 }\end{array}$ & $\begin{array}{c}\text { あまり } \\
\text { 重要でない }\end{array}$ & $\begin{array}{c}\text { 全く重要 } \\
\text { でない }\end{array}$ \\
\hline \multirow{3}{*}{$\begin{array}{l}\text { 16. 自分のペース（進度）で } \\
\text { 勉強できること }\end{array}$} & N3 & 81 & 126 & 22 & 3 \\
\hline & N4 & 71 & 143 & 21 & 2 \\
\hline & N5 & 37 & 72 & 11 & 2 \\
\hline \multirow[t]{3}{*}{ 17. 自分にやる気があること } & N3 & 121 & 102 & 6 & 3 \\
\hline & $\mathrm{N} 4$ & 117 & 113 & 6 & 1 \\
\hline & N5 & 65 & 54 & 1 & 2 \\
\hline \multirow{3}{*}{$\begin{array}{l}\text { 18. 日本や日本語自体に魅力が } \\
\text { あること }\end{array}$} & N3 & 149 & 72 & 10 & 1 \\
\hline & $\mathrm{N} 4$ & 131 & 97 & 6 & 3 \\
\hline & N5 & 64 & 51 & 4 & 3 \\
\hline
\end{tabular}

\subsection{3 日本語学習の意義}

「日本語を勉強することについて、あなたはどのような意義があると思いますか」 という質問には、自由記述で回答された単語、文からキーワードを抜粋した。最も 多く記述されたキーワードはレベルを問わず「日本文化を理解する」であった。 以下、「趣味」、「日本人とのコミュニケーション」、「もっと多くのスキルを身に 付ける」などであった。そのほか「自己充実」、「人生の意義」「目標や夢を叶える」、 「自信がつく」、「自己にチャレンジする」「未知の世界を探求する」などがあった。

表 5 日本語学習の意義

\begin{tabular}{|l|c|c|c|}
\hline \multicolumn{1}{|c|}{ キーワード } & $\mathrm{N} 3$ & $\mathrm{~N} 4$ & $\mathrm{~N} 5$ \\
\hline 日本文化を理解する & 33 & 49 & 17 \\
\hline 趣味 & 31 & 31 & 17 \\
\hline 日本人とコミュニケーション & 24 & 19 & 15 \\
\hline もっと多くのスキルを身に付ける & 24 & 23 & 6 \\
\hline おもしろい & 15 & 12 & 11 \\
\hline 仕事に必要 & 15 & 12 & 4 \\
\hline 自己充実 & 3 & 18 & 5 \\
\hline 旅行に便利 & 7 & 11 & 6 \\
\hline 自己にチャレンジする & 11 & 5 & 4 \\
\hline アニメと漫画の内容を知る & 8 & 8 & 2 \\
\hline
\end{tabular}




\begin{tabular}{|l|c|c|c|}
\hline \multicolumn{1}{|c|}{ キーワード } & $\mathrm{N} 3$ & $\mathrm{~N} 4$ & $\mathrm{~N} 5$ \\
\hline 使い道が広い & 5 & 8 & 3 \\
\hline $\begin{array}{l}\text { もうーつの外国語をマスターできると } \\
\text { プラスになる }\end{array}$ & 10 & 4 & 0 \\
\hline 学習過程を楽しむ & 2 & 6 & 2 \\
\hline 人生の意義 & 6 & 2 & 0 \\
\hline 未知の世界を探求する & 3 & 2 & 3 \\
\hline 目標や夢を叶える & 6 & 1 & 0 \\
\hline 好きなアイドルを理解できる & 5 & 1 & 0 \\
\hline 重要 & 3 & 1 & 2 \\
\hline 自信がつく & 3 & 1 & 1 \\
\hline 日本が好き & 3 & 1 & 0 \\
\hline 日本人と知り合いになる & 1 & 0 & 1 \\
\hline 日本語の発音は綺麗 & 0 & 1 & 0 \\
\hline 移民 & 0 & 2 & 0 \\
\hline 日中関係を知る & 0 & 1 & 0 \\
\hline 試験 & 0 & 0 \\
\hline
\end{tabular}

\section{6. まとめ}

\section{1 日本旅行中の日本語の使用機会場面}

日本旅行のときの日本語使用機会場面について、N3 の協力者は「1.買い物する とき」、「2.食事をするとき」、「5.街中で（道を探すときなど）」の場面において 「とてもある」と答えていた。N4、N5 レベルでは日本語を使用する機会が少なかった が、N3 レベルでは各場面でより有用な情報を得るためなど、積極的に日本語を使用 していることが推測できる。もちろん日本語を使わずとも買い物、食事、道を探す ことなどはできる。ただ、英語などほかの言語があまり通じないと予想される日本 旅行の場面では、日本語を使用することによって、自分が欲しいものや情報がより 容易に、効率よく獲得されるであろう。一方、「6.コンサートなどイベントに参加 するとき」、「7.日本の友達と会うとき」、「8. 体験教室（和菓子作り、浴衣など）に 参加するとき」は日本語を使う機会場面は「全くない」という回答が多かった。 その理由としては、それらの場面に接する機会が少ないのかもしれない。ただ、 すべての場面で「とてもある」と答えたのは N3 の協力者だったことは、レベルに よって日本語使用機会に影響があると考えられる。 


\section{2 日本語学習の継続に必要なもの}

日本語学習の継続に必要なものとして「とても重要」と選ばれた項目は、全レベル で「3.旅行に役立つこと」、「4.自分の趣味（アニメ、ゲームなど）に役立つこと」 と N3 の協力者の「1. 就職、進学などに役立つこと」であり、「役立つこと」が重要 であることが確認された。これは山下ほか（2017）の学習動機の要因である「実用 的価值認識」と述心゙られているものと共通している。また、N3 の協力者は「とても 重要」に、「7. 日本語や日本文化に触れる機会があること」、「8.日本人と交流する 機会があること」に回答が多かったことは、瀬尾（2011）が概念化した他者との 「つながり」と同様であると考える。そして、「17. 自分にやる気があること」を選択 した協力者が多かったが、「やる気」を高めるために、日本語教育関係者は何が できるであろうか。

\section{3 日本語学習の意義}

日本語学習の意義について、最も多く記述されたキーワードはレベルを問わず、 「日本文化を理解する」であった。6.2「日本語学習の継続に必要なもの」として 「役立つ」に関連した項目が多く選択されていたが、自由記述において「役立つ」 というキーワードは現れなかった。そのほかに「自己充実」、「人生の意義」、「目標 や夢を叶える」「自信がつく」、「自己にチャレンジする」、「未知の世界を探求する」 などがみられることからも協力者にとって道具的な日本語の意義は低いと思われる。

ギブソンは「学習が進むにつれ日本に対する理解を深め、日本文化や日本語母語 話者との心理的距離をさらに縮めたいという気持ちが強くなる課程がみられた」 （2009：187）と述べている。本調查でもレベルが上がるにつれ、より日本人との 交流や日本語使用機会が増え、日本語文化を理解する、日本人とコミュニケーション するという日本語学習の意義とつながっているのではないかと考えられる。

\section{7. おわりに}

日本語レベルが高くなると、その使用機会場面は増え、日本語を学習する意義も 交流への期待が大きくなる。瀬尾（2016）は、香港における学習者のさまざまな 生活、多様な学びを受け容れ、言語習得のみを目指寸日本語教育からの脱却を提案 している。学習者の多様化ということばが注目され久しいが、やはり言語の習得から 展開される学習者の世界の広がりを支援していく必要があるのではないだろうか。

また、日本語教師、教育機関は、日本語学習を提供する立場として、具体的な 文法や表現を教えることに加え、さまざまな場面において学習者自身が対応できる ストラテジー能力の養成にも力を入れるべきではないか。そして、それが言語習得 から学習者の世界を広げる支援にもつながるのではないかと考える。学習動機を 
高めるための調査において岩本（2010）は、「学習支援者の存在」「「自己効力感」、 「成功体験」「「自律学習」が大変重要な役割を担っているとしている。本調查結果を もとに日本語教師として、日本語教育機関として、学習者に提供、支援できること は何かそれぞれが再考寸る機会となれば幸いである。

本調查ではレベルの違いによる日本語使用機会場面などが明らかになったが、 調査対象者は N5、N4、N3 レベルのみであった。今後の課題として、さらに N2、 N1レベルを対象とした調查を実施したいと考える。

\section{【謝辞】}

日本語能力試験協力委員会のメンバーである以下の方々には貴重なご提案や ご助言をいただきました。心よりお礼を申し上げます。

（名字の日本読み女いうえお順）

杉田 雅彦 在香港日本国総領事館広報文化部長

趙 達栄＼cjkstart香港日本文化協会副会長

陳 志誠 元香港城市大学教授

余均灼 元香港中文大学教授 


\section{参考文献}

板井美佐(2001)「香港における中国人学習者の日本語学習に対する動機(BF)、学習 ST 及び学習 活動上の好みに関寸る調査 : 香港 4 大学機関の調査から」『筑波大学留学生センター日本語 教育論集』16,83-104

岩本尚希（2010）「外国語学習者の学習継続要因に関する一考察：言語学習ヒストリーから」

『桜美林言語教育論叢』6,29-43

宇田川洋子・李夢娟・李澤森・劉礪志（2013）「香港の日本語能力試験受験者減少の要因を探る」

『日本學刊』第 16 号,233-246

宇田川洋子・李夢娟・李澤森・劉碱志（2014）「香港の日本語学習者減少の要因－調査報告－」

『日本學刊』第 17 号,107-120

ギブソン壽美子（2009）「香港における社会人の日本語学習動機の一研究一動機の変化を

中心に一」『第 8 回国際日本語教育・日本研究シンポジウム会議録 アジア・オセアニア地域に

おける多文化共生社会と日本語教育・日本研究』182-188

木山登茂子・中野貴子・周宏陽・上田早苗・望月貴子・蘇凱達・青山玲二郎（2011）「2010 年

香港日本者背景調查報告」『日本學刊』第 14 号,176-195

国際交流基金（2013）「日本語教育機関調查・2012 年海外の日本語教育の現状」

小玉博昭（2017）「競合言語としての韓国語-香港における日本語教育との比較から-」『日本學刊』

第 20 号,32-46

瀬尾匡輝（2011）「香港の日本語生涯学習者の動機付けの変化一修正版グラウンデッド・ セオリー・アプローチを用いた分析から探るー」『日本學刊』第 14 号,16-39

瀬尾匡輝・陳德奇・司徒棟威（2012）「なぜ日本語学習をやめてしまったのか一香港の社会人 教育機関の学習者における動機減退要因の一事例一」『日本學刊』第 15 号,80-99

瀬尾悠希子（2016）「日本語から韓国語へ移行する学習者達一香港の成人学習者へのインタ ビューからー」『日本學刊』第 19 号,49-63

日本政府観光局 $<$ https://www.jnto.go.jp/jpn/news/press_releases/pdf/170117_monthly.pdf $>$

$<$ https://www.jnto.go.jp/jpn/statistics/marketingdata_tourists_after_vj.pdf $>$

山下直子・梁安玉・劉礪志・李澤森・李夢娟（2016）「2015 年香港日本語学習者背景調查報告」

『日本學刊』第 19 号,185-197

山下直子・梁安玉・劉獂志・李澤森・李夢娟（2017）「2016 年香港日本語学習者背景調查報告一 年少者と成人の学習動機一」『日本學刊』第 20 号,117-124 